\title{
PENDEKATAN TEKSTUAL DAN KONTEKSTUAL DALAM STUDY HADIST
}

\author{
Firad Wijaya, Andri Afriani \\ IAIH Anjani Lombok Timur \\ STAI Darul Kamal NW Kembang Kerang NTB \\ Firadwijava93@gmail.com \\ andriafriani.aa@gmail.com
}

\begin{abstract}
Abstrak
Pendekatan tekstual dan Kontekstual sangat berarti dalam pemahaman keilmuan hadits. Dengan pendekatan tekstual dan kontekstual kita dapat ketahui bahwa suatu hadits muncul tidak serta merta begitu saja, melainkan karena ada sebab-musababnya. Pendekatan tekstual lebih cenderung berlaku pada ibadah Mahdah (Murni) antara hubungan manusia dengan Tuhan atau yang sering kita sebut dengan (Hablumminallab) seperti Shalat misalnya.Sedangkan pendekatan kontekstual lebih melihat pada konteks historis, sosiologis dalam kultural dan temporal suatu hadits sehingga dalam memahami hadits tidaklah begitu baku tapi lebih bijaksana dengan mengkaji keadaan kontemporer masyarakat sekarang tanpa menghilangkan ruh dari nash hadits tersebut.
\end{abstract}

Kata Kunci : Tekstual, Kontekstual, Study Hadist

\section{PENDAHULUAN}

Al-qur'an dan Al-Hadits merupakan dua pegangan ummat Islam yang diwariskan oleh Baginda Nabi Besar Muhammad SAW. Al-qur'an dan Hadits hadir sebagai peringatan, serta petunjuk bagi ummat Islam dalam mengarungi kehidupan yang fana di muka bumi ini. Al-qur'an merupakan kalimat-kalimat Allah SWT yang indah dan tertata baik secara komprehensif. Sementara Hadits adalah semua laporan yang isinya tentang Nabi baik perbuatan, perkataan ataupun ketetapan Nabi SAW.

Selain itu, hadist atau As-Sunnah merupakan salah satu sumber ajaran Islam yang menduduki posisi sangat signifikan di kalangan para ilmuan terkemuka di 
masa lampau, baik secara struktural maupun fungsional. Secara struktural menduduki posisi kedua setelah Al-qur'an, namun jika dilihat secara fungsional, ia merupakan bayan (eksplanasi) terhadap ayat-ayat Al-qur'an yang bersifat global atau mutlaq ${ }^{1}$.

Secara tersirat, Al-Qur'an pun mendukung ide tersebut, antara lain firman Allah SWT:

"Keterangan-keterangan (mukjizat) dan kitab-kitab. dan Kami turunkan kepadamu Al Quran, agar kamu menerangkan pada umat manusia apa yang telah diturunkan kepada mereka[829] dan supaya mereka memikirkan. (Q.S An-Nahl: 44)

Yakni: perintah-perintah, dan larangan-larangan, aturan dan lain-lain yang terdapat dalam Al Quran.

Untuk itu, dalam memahami hadits yang baik sangat banyak disiplin dan metode ilmu yang dapat digunakan, salah satunya dengan studi hadits dengan teori dan metodologi yang akurat. Sehingga pendekatan tekstual dan kontekstual dalam studi hadits juga berfungsi dalam memahami hadits sebagaimana yang akan kami bahas berikut. $^{2}$

\section{Pengertian Tekstual dan Kontekstual dalam Studi Hadits}

\section{Tekstual}

Tekstual berasal dari kata teks yang berarti kata-kata asli dari pengarang, kutipan dari kitab suci untuk pangkal ajaran atau alasan, bahan tertulis sebagai dasar memberikan pengajaran. ${ }^{3}$

Pendekatan tekstual adalah cara memahami hadis yang cenderung memfokuskan pada data riwayat dengan menekankan kupasan dari sudut gramatika bahasa dengan pola pikir episteme bayani. Eksesnya, pemikiranpemikiran ulama terdahulu dipahami sebagai sesuatu yang final dan dogmatis.

1. Dr. H.M.Syuhudi Ismail, Hadis Nabi yang Tekstual dan Kontekstual (Jakarta: PT Bulan Bintang, 1994), hlm 5

${ }^{2}$ Fazlur Rahman, "Wacana Studi Hadis Kontemporer" dalamBungaRampai Wacana Studi Hadis Kontemporer, ed. Hamim Ilyas dan Suryadi(Yogyakarta: Tiara Wacana, 2002), hlm119.

${ }^{3}$ Tim Penyusun Kamus Pusat Pembinaan dan pengembangan Bahasa, Kamus Besar Bahasa Indonesia, (Jakarta: Balai Pustaka, 1998), hlm 916. 
Analisa teks hadits sebagai upaya menemukan pesan-pesan moral atau pesan-pesan agama yang terkandung di dalamnya, ada beberapa asumsi dasar yang perlu digarisbawahi. Tanpa landasan yang jelas dalam proses pemahaman, seorang analisis tidak dapat menentukan pangkal tolak analisisnya dan tidak dapat memilih dan memilah kasus-kasus kehadisan. Tanpa itu, dapat saja orang akan terjebak pada kasus yang sesungguhnya merupakan masalah marginal dalam agama dan mengabaikan atau tidak berkesempatan menelaah, memikirkan, dan mengembangkan hal-hal yang bersifat substantif. Orang dapat terjebak dan disibukkan oleh warna kulit tanpa sempat menguak isinya.

Pada kasus-kasus yang bersifat kontekstual dapat saja orang terkurung oleh formalisme tekstual, atau sebaliknya pada kasus-kasus yang sangat tekstual dibolak-balik sehingga makna kesucian agama menjadi hilang. Karena itulah, kiranya sangat diperlukan sejumlahasumsi dasar atau postulasi keilmuan Islam sebagai acuan dan titik awal kajian teks hadits. ${ }^{4}$

\section{Kontekstual}

Kata "kontekstual" berasal dari "konteks" yang dalam Kamus Besar Bahasa Indonesia mengandung dua arti: 1. bagian sesuatu uraian atau kalimat yang dapat mendukung atau menambah kejelasan makna; 2. situasi yang ada hubungan dengan suatu kejadian ${ }^{5}$. Kedua arti ini dapat digunakan karena tidak terlepas istilah dalam kajian pemahaman Hadis.

Pendekatan kontekstual, menurut Qamaruddin Hidayat, seorang penafsir memposisikan sebuah teks ke dalam sebuah jaringan wacana, hal itu diibaratkan sebuah gunung es, teks adalah fenomena kecil dari puncak gunung yang tampak di permukaan. Oleh karena itu tanpa mengetahui latar belakang sosial budaya dari mana dan dalam situasi apa sebuah teks muncul, maka sulit menangkap makna pesan dari sebuah teks. ${ }^{6}$

${ }^{4}$ Dr. Daniel Juned, Ilmu Hadits:Paradigma Baru dan Rekonstruksi Ilmu Hadits, (Yogyakarta: Erlangga, 2010), hlm 31

${ }^{5}$ Tim Penyusun Kamus Pusat Pembinaan dan pengembangan Bahasa, hlm 458.

${ }^{6}$ Ibid.,hlm 214. 
Sama dengan Al-qur'an, sejumlah hadits dalam upaya pemahaman sangat erat hubungannya dengan konteks tertentu, misalnya kapan Rasulullah menyampaikan berita atau bersikap, bertindak atau berperilaku, dimana, dalam kondisi bagaimana, kepada siapa beliau menyampaikan, dan sebagainya.

\section{Memahami Hadits Secara Tekstual dan Kontekstual}

Secara garis besar, ada dua tipologi pemahaman ulama atas hadis:pertama, pemahaman atas hadis Nabi tanpa mempedulikan proses sejarah yang melahirkannya "ahistoris", tipologi inidisebut tekstualis; kedua, pemahaman kritis denganmempertimbangkan asal-usul (asbab al-wurud) hadis, dan konteksyang mengitarinya, pemahaman hadis dengan cara yangdemikian, disebut kontekstual.

Pemahaman kontekstual atas hadis menurut Edi Safri adalahmemahami hadis-hadis Rasulullah dengan memperhatikan danmengkaji keterkaitannya dengan peristiwa atau situasi yangmelatarbelakangi munculnya, atau dengan kata lain,memperhatikan dan mengkaji konteksnya. Dengan demikianasbab al-wurud dalam kajian kontekstual merupakan bagian yangpaling penting. Hal kajian yang lebih luas tentang pemahamankontekstual tidak hanya terbatas pada asbab al-wurud dalam artikhusus seperti yang biasa dipahami, tetapi lebih luas dari itumeliputi konteks historis-sosiologis di mana asbab al-wurudmerupakan bagian darinya. ${ }^{7}$

Dengan demikian, pemahaman kontekstual atas hadis Nabi berarti memahami hadis berdasarkan peristiwa-peristiwa dansituasi ketika hadis diucapkan, dan kepada siapa hadis ituditujukan. Artinya, hadis Nabi saw. dipahami melalui redaksilahiriah dan aspek-aspek kontekstualnya. Meskipun di sinikelihatannya konteks historis merupakan aspek yang palingpenting dalam sebuah pendekatan kontekstual, namun konteksredaksional juga tak dapat diabaikan. Aspek terakhir itu tak kalahpentingnya dalam rangka membatasi dan menangkap maknayang lebih luas (makna filosofis) sehingga hadis tetap menjadikomunikatif.

\footnotetext{
${ }^{7}$ Liliek Channa AW,Memahami Makna Hadis secara Tekstual dan Kontekstual, Jurnal Studi Keislaman, vol xv no 02, Desember 2011, hal 396,http:/ / ejurnal.iainmataram.ac.id/index.php/ulumuna/article/view/205/pdf_98Edi Safri, Al-Imâm al-Syafi'i: Metode Penyelesaian Hadis-Hadis Mukhtalif, Tesis. Diakses 15 November 2016 pukul 13.00 WIB
} 
Pemahaman kontekstualitas ini sebagai sebuah teori dalam lintasan sejarah sudah diawali pembahasannya oleh Imam Syafi'I dalam kitabnya, Ar-Risalah, dan kitab yang lebih khusus, Ikhtilaf al-hadits. Termasuk dalam nuansa ini juga, karyakarya para ahli hadits yang berbicara tentang asbab al-wurud al-hadits, seperti yang ditulis as-Suyuthi. ${ }^{8}$

Dalam diskursus ilmu hadis juga dikenal bahwa hadis itu ada yang memiliki asbabul wurud khusus, ada pula yang tidak. Untuk kategori pertama, yakni hadishadis yang memiliki sebab khusus kita dapat menggunakan perangkat ilmu yang disebut asbabul wurud dalam memahami maknanya. Persoalannya adalah bagaimana jika suatu hadis itu tidak memiliki asbabul wurud secara khusus. Disinilah barangkali relevansi judul yang penulis tawarkan, yakni adanya kemungkinan melakukan analisis pemahaman hadis (fiqhul hadis) dengan pendekatan historis, sosiologis, antropologis bahkan mungkin pendekatan psikologis.

Hal itu berangkat dari suatu asumsi dasar bahwa ketika Nabi SAW bersabda pasti beliau tidak lepas dari situasi kondisi yang melingkupi masyarakat pada waktu itu. Dengan lain ungkapan, adalah mustahil Nabi SAW bicara dalam ruang yang hampa sejarah (vakum historis). Bagaimanapun sebuah gagasan atau ide termasuk dalam hal ini bersabda Nabi SAW. Selalu based on historical problems, yakni terkait dengan problem historis-kultural waktu itu. ${ }^{9}$

Dengan pendekatan-pendekatan historis, sosiologis, dan antropologis semacam itu, diharapkan akan mampu memberikan pemahaman hadis yang relatif lebih tepat, apresiatif dan akomodatif terhadap perubahan dan perkembangan zaman. Sehingga dalam memahami hadis kita tidak hanya terpaku pada dhahirnya teks hadis, melainkan harus memperhatikan konteks sosio-kultural waktu itu.

Dengan demikian, hadis-hadis Nabi SAW. Sebagai mitra al-Qur'an, secara teologis juga diharapkan dapat memberi inspirasi untuk membantu menyelesaikan problem-problem yang muncul dalam masyarakat kontemporer sekarang. Karena bagaimanapun tampaknya kita sepakat bahwa pembaharuan islam atau

${ }^{8}$ Dr. Daniel Juned, hlm 33-34.

${ }^{9}$ Dr.H. Said Agil Husin Munawwar, Asbabul Wurud Studi Kritis Hadis Nabi Pendekatan SosioHistoris-Kontekstual (Yogyakarta: Pustaka Pelajar 2001), hlm 25 
reaktualisasi ajaran Islam harus mengacu kepada teks-teks yang menjadi landasan ajaran Islam itu sendiri, yakni al-Qur'an dan al-Hadis. ${ }^{10}$

Yang dimaksud dengan pendekatan historis dalam hal ini adalah suatu upaya memahami hadis dengan cara mempertimbaingkan kondisi historis, empiris pada saat hadis itu disampaikan Nabi SAW. Dengan kata lain, pendekatan historis adalah pendekatan yang dilakukan dengan cara mengaitkan antara ide atau gagasan yang terdapat dalam hadis dengan determinasi-determinasi sosial dan situasi historis kultural yang mengintarinya.

Pendekatan model ini sebenarnya sudah dirintis oleh para ulama hadis sejak dulu, yaitu dengan munculnya ilmu Asbab al-Wurud yaitu suatu ilmu yang menerangkan sebab-sebab mengapa Nabi menuturkan sabdanya dan masa-masa Nabi menuturkannya. Atau ilmu yang berbicara mengenai peristiwa-peristiwa atau pertanyaan-pertanyaan yang terjadi pada hadis disampaikan oleh Nabi. ${ }^{11}$

Adapun pendekatan sosiologi menyoroti dari sudut posisi manusia yang membawanya kepada perilaku itu. Sedangkan antropologi memperhatikan terbentuknya pola-pola perilaku itu pada tatanan nilai yang dianut dalam kehidupan masyarakat manusia.

Kalau kita mencoba menggambarkannya dengan pendekatan historis, sosiologis, dan antropologis secara sintetik, maka hadis yang juga merupakan fenomena keagamaan dan yang berakumulasi pada perilaku manusia dapat didekati dengan menggunakan ketiga model pendekatan tersebut, sesuai konteks masing-masing. Tegasnya, pendekatan historis, sosiologis, dan antropologis dapat disebut sebagai asbabul wurud'am (asbabul wurud secara makro).

Adapun aplikasi pemahaman hadis dalam pendekatan historis, sosiologis, dan antropologis sebagai berikut.

Hadis Tentang Larangan Wanita Berpergian Sendirian

Bunyi Hadis:

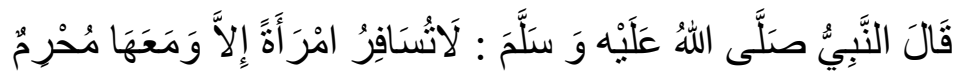

${ }^{10} \mathrm{Ibid}, \mathrm{hlm} 26$

${ }^{11}$ Ibid, hlm 27-28 
“Tidak dibolehkan seorang perempuan (berpergian jauh-jauh) kecuali ada seorang mahram bersamanya."(H.R. al-Bukhari dan Muslim).

Hadis tersebut, sebagaimana dijelaskan oleh Imam an-Nawawi dalam kitab Syarh Muslim dipahami oleh jumhur ulama sebagai suatu larangan bagi wanita untuk berpergian yang bersifat sunnah atau mubah, tanpa disertai mahram atau suaminya. Sedangkan untuk berpergian yang sifatnya wajib, seperti menunaikan ibadah haji, para ulama berbeda pendapat.

Menurut Imam Abu Hanifah dan didukung oleh mayoritas ulama hadis, adalah wajib hukumnya wanita yang mau haji, harus disertai mahram atau suaminya. Namun menurut Imam Malik, al-Auza’i dan asy-Syafi'i, tidak wajib. Mereka hanya mensyaratkan "keamanan" saja. Keamanan itu bisa diperoleh dengan mahram atau suami atau wanita-wanita lain yang terpercaya (tsiqat). Dengan demikian, jika pemikiran itu kita kembangkan, maka konsep "mahram" yang tadinya bersifat personal, dapat digantikan dengan sistem keamanan yang menjamin keselamatan dan kemanan wanita itu.

Sepanjang penelitian penulis, hadis tersebut tidak mempunyai asbabul wurud khusus. Sementara, jika kita melihat kondisi historis dan sosiologis masyarakat saat itu, sangat mungkin larangan itu dilatarbelakangi oleh adanya kekhawatiran Nabi SAW akan keselamatan perempuan, jika dia berpergian jauh tanpa disertai suami dan mahram. Mengingat pada masa itu, ketika seseorang berpergian, ia biasa menggunakan kendaraan onta, bighal, (sejenis kuda) maupun keledai dalam perjalanannya. Mereka seringkali harus mengarungi padang pasir yang luas, daerah-daerah yang jauh dari lautan manusia. Disamping itu, sistem nilai yang berlaku pada saat itu, wanita dianggap tabu atau kurang etis jika pergi jauh sendirian. Dalam kondisi seperti itu tentunya seorang wanita yang berpergian tanpa disertai suami ataupun mahramnya dikhawatirkan keselamatan dirinya, atau minimal nama baiknya akan tercemar.

Oleh sebab itu,jika kondisi masyarakat sekarang sudah berubah. Di mana jarak yang jauh sudah tidak lagi menjadi masalah, ditambah dengan adanya sistem keamanan yang menjamin keselamatan wanita dalam berpergian maka sah-sah saja wanita pergi sendirian untuk menuntut ilmu, menunaikan haji, bekerja dan lain sebagainya. 
Dengan demikian, di sini perlu reinterpretasi baru mengenai konsep mahram. Mahram tidak lagi harus dipahami sebagai person akan tetapi sistem keamanan yang menjamin keselamatan bagi kaum wanita itu. Pemahaman semacam ini tampaknya akan lebih kontekstual, apresiasip dan akomodatif terhadap perubahan dan perkembangan zaman. Sehingga kita tidak hanya terpaku dan terjebak oleh bunyi teks hadis yang kadang cenderung bersifat kultural, temporal, dan lokal.

Pemahaman yang mempertimbangkan konteks historis, sosiologis, dan antropologis cenderung lebih lentur, kenyal, dan elastis. Namun kemudian hal ini, tidak berarti kita harus kehilangan ruh semangat nilai yang terkandung dalam hadis tersebut.

Kontekstualisasi pemahaman hadis tersebut diatas, didukung oleh data yang valid dari kandungan hadis yang marfu’(sampai Rasulullah) yang diriwayatkan alBukhari dari 'Ady bin Hatim, sebagai berikut:

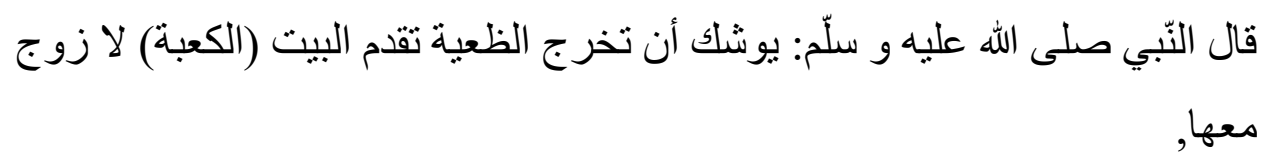

"Akan datang masanya, seorang perempuan penunggang onta pergi dari kota (Hijrah) menuju Ka’bah tanpa seorang suami bersamanya.”(HR. Al-Bukhari).

Hadis tersebut sesungguhnya memberikan prediksi tentang datangnya masa kejayaan Islam dan keamanan di seantero dunia dan sekaligus juga menunjukkan dibolehkannya wanita berpergian tanpa suami atau mahram. Demikian kesimpulan Ibnu Hazm sebagaimana dikutip oleh Yusuf Qardhawi. ${ }^{12}$

Hadis Tentang Larangan Melukis

Bunyi Hadisnya :

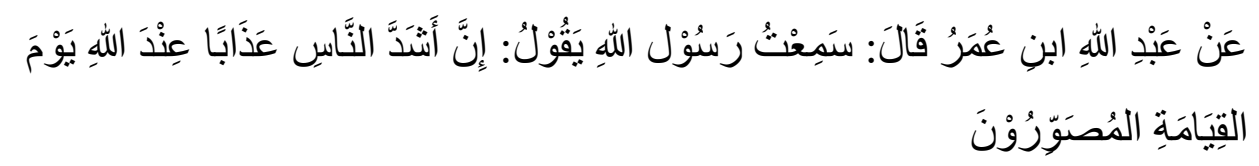

"Sesungguhnya orang akan disiksa paling keras disisi Allah adalah para pelukis."(HR. Al-Bukhari dan Muslim).

${ }^{12}$ Ibid, hlm 31-32 
Secara tekstual, hadis tersebut memberikan pengertian mengenai larangan menulis makhluk bernyawa. Bahkan para Imam Madzab sepakat mengenai keharaman menggambar, memajang, dan menjualnya.

Kesimpulan semacam ini bisa dipahami, karena banyaknya riwayat mengenai masalah menggambar tersebut. Sebagaimana juga diriwayatkan dalam hadis yang lain bahwa para pelukis pada hari kiamat kelak dituntut untuk memberikan nyawa kepada apa yang dilukisnya didunia. Malaikat juga tidak akan masuk di rumah yang di dalamnya ada lukisannya.

Namun demikian, masalahnya adalah apakah kita tidak perlu melacak kembali mengenai akar-akar historis, sosiologis, dan antropologis dan bahkan psikologis masyarakat pada waktu hadis tersebut disampaikan Nabi SAW?Jawabnya tegas"tentu perlu”. Sebab larangan melukis dan memajang lukisan tersebut tentu tidak lepas dari "setting, historis, sosiologis" masyarakat pada waktu itu. Mereka secara historis-sosiologis dan bahkan psikologis belum lama sembuh dari penyakit syirik, yakni menyekutukan Allah dengan menyembah patung-patung, berhala, dan sebagainya.

Dalam kapasitasnya sebagai rasul, Nabi SAW berusaha keras agar masyarakat umat Islam waktu itu benar-benar sembuh dari kemusyrikan tersebut. Salah satu cara yang ditempuh adalah dengan mengeluarkan larangan melukis, memproduksi, dan memajang lukisan atau berhala. Bahkan disertai dengan diancam siksaan keras, baik yang memproduksi maupun yang memajangnya. ${ }^{13}$

Menurut penulis, larangan tersebut lebih bersifat syaddu dzara'i agar masyarakat tidak terperosok kembali ke dalam kemusyrikan terutama pada penyembahan patung dan gambar. Sedangkan untuk zaman sekarang, tampaknya menjadi kurang relevan lagi untuk melarang seseorang melukis, berkreasi seni, sebab hal itu merupakan bagian dari ekspresi kejiwaan seorang pelukis.

Namun yang perlu digarisbawahi bahwa lukisan yang dibuatnya, harus tetap menjaga nilai-nilai etis-agamis. Artinya bukan lukisan yang berbau pornografis dan dapat merangsang birahi orang yang melihatnya. Dengan demikian, hendaknya

${ }^{13}$ Ibid, hlm 33 
para pelukis tetap menjaga nilai-nilai etika. Jangan sampai pada dalih seni, lalu kita bebas melakukan apa saja.

Jika kita melihat sejarah masa lalu, khususnya zaman Nabi Sulaiman AS. Kesenian membuat patung ternyata mendapat apresiasi dari Allah SWT. Sehingga dengan demikian, dapat dipahami larangan tersebut bersifat kondisional dan temporal, karena terdapat kaedah Ushul Fiqh yang menyatakan "al-Hukmu Yaduru Ma'a 'illatibi wujudan wa 'adaman”artinya, hukum itu berkisar (tergantung) pada ada atau tidak adanya suatu 'illat. Jika 'illat itu berubah, maka hukum pun menjadi berubah. Dan disinilah letak fleksibilitas dan elastisitas hukum islam. ${ }^{14}$

Pemahaman antara para ulama di atas juga berbeda berkaitan dengan suatu teks hadis. Ada yang memahaminya secara tekstual dan ada pula yang kontekstual. Kedua ciri ini sebenarnya telah dikenal bahkan dipraktekkan oleh para sahabat Nabi SAW. ${ }^{15}$

Suatu ketika, Nabi SAW memerintahkan sejumlah sahabatnya untuk pergi ke perkampungan Bani Quraizah. Sebelum berangkat, beliau berpesan: La Yushaliyanna ahadukum al-ashra illa fi Bani Quraizhah"(Janganlah ada salah seorang satu di antara kamu yang shalat Ashar, kecuali di perkampungan Bani Quraizah).

Perjalanan ke perkampungan tersebut ternyata begitu panjang, sehingga sebelum mereka tiba di tempat yang dituju, waktu Ashar telah habis. Di sini, mereka merenungkan kembali apa maksud pesan Nabi di atas. Ternyata sebagian memahaminya sebagai perintah untuk bergegas dalam perjalanan agar dapat tiba di sana pada waktu masih Ashar. Jadi, bukan seperti bunyi teksnya yang melarang shalat Ashar walaupun belum tiba di tempat yang dituju.

Tetapi sebagian yang lain memahaminya secara tekstual. Oleh karena itu, mereka baru melakukan shalat Ashar setelah waktu Ashar berlalu, karena mereka baru tiba di perkampungan Bani Quraizah (tempat yang ditunjuk oleh teks perintah Nabi) setelah waktu Ashar berlalu.

${ }^{14}$ Ibid, hlm 35

${ }^{15}$ Syaikh Muhammad Al-Ghazali, Studi Kritis Atas Hadis Nabi Antara Pemahaman Tekstual dan Kontekstual, (Bandung: Mizan, 1996), hlm 8. 
Memang benar, bahwa para ulama mengenal istilah asbab al wurud, yakni sebab diucapkan atau diperankannya sebuah hadis atau kata lain,"konteks sebuah hadis". Namun, tidak jarang konteks dimaksud tidak diketahui secara pasti, atau kabur bagi sebagian peneliti, sehingga menimbulkan kekeliruan pemahaman. Sebagian ulama memahami sabda Nabi, "Man akala lahma jazurin falyatawadhdha"(siapa yang makan daging unta hendaklah berwudhu), sebagai argumentasi (dalil) batalnya wudhu akibat makan daging unta. Pemahaman ini keliru akibat tidak jelasnya konteks ucapan Nabi itu baginya. ${ }^{16}$

Adapun batas-batas tekstual dan kontekstual hadisSecara umum M. Sa'ad Ibrahim menjelaskan bahwa batasankontekstual meliputi dua hal, yaitu:

1. Dalam bidang ibadah mahdhah (murni) tidak ada atau tidakperlu pemahaman kontekstual. Jika ada penambahan dan pengurangan untuk penyesuaian terhadap situasi dan kondisi,maka hal tersebut adalah bid ’ah.

2. Bidang di luar ibadah murni (ghairu mahdhah). Pemahamankontekstual perlu dilakukan dengan tetap berpegang pada moral ideal nas, untuk selanjutnya dirumuskan legal spesifik baru yang menggantikan legal spesifik lamanya.

MenurutSuryadi, batasan-batasan tekstual (normatif) meliputi:

1. Ide moral/ide dasar/tujuan di balik teks (tersirat). Ide ituditentukan dari makna yang tersirat di balik teks yangsifatnya universal, lintas ruang waktu, dan inter subjektif.

2. Bersifat absolut, prinsipil, universal, dan fundamental. ${ }^{17}$

3. Mempunyai visi keadilan, kesetaraan, demokrasi,mu'asyarah bi al-ma'ruf.

4. Terkait relasi antara manusia dan Tuhan yang bersifat universal artinya segala sesuatu yang dapat dilakukansiapapun, kapan pun dan di mana pun tanpa terpengaruholeh letak geografis, budaya dan historis tertentu.Misalnya "shalat", dimensi tekstualnya terletak pada keharusan seorang hamba untuk melakukannya(berkomunikasi, menyembah atau beribadah) dalamkondisi apapun selama hayatnya. Namun

16Ibid, hlm 9

${ }^{17}$ Fazlur Rahman, "Wacana Studi Hadis Kontemporer" dalamBungaRampai Wacana Studi Hadis Kontemporer, ed. Hamim Ilyas dan Suryadi(Yogyakarta: Tiara Wacana, 2002), hlm119. 
memasukiranah "bagaimana cara muslim melakukan shalat" sangattergantung pada konteks si pelakunya.

Berdasarkan penjelasan di atas dapat dipahami, mengapa untuk ibadah murni (mabdhah) tidak perlu dipahami secaratekstual. Menurut analisa penulis di sinilah peran Muhammadsebagai Rasulullah, beliau punya otoritas penuh tanpa campurtangan ra'yu manusia, dan itulah yang dimaksud firman Allah:"dan tidaklah yang diucapkannya itu menurut hawa nafsunya.Ucapannya itu tiada lain hanyalah wahyu yang diwahyukankepadanya."

Sedangkan di luar ibadah murni (ghayru mahdhah) diperlukanpemahaman secara kontekstual dengan tetap berpegang padamoral ideal atau nas mengingat Muhammad saw. itu sebagaiRasulullah di akhir zaman sehingga syari atnya berlaku untukkapan dan di mana saja.

Di samping itu perlu dipahami pula,bagaimana posisi hadis disampaikan. Apakah Muhammad saw.dalam posisi sebagai qadli (hakim), pemimpin negara ataumanusia biasa. Hal itu dapat dilihat pula, apa yang dilakukan olehsebagian sahabat terhadap hadis "jangan kamu shalat ashar,kecuali di perkampungan Bani Quraydhah," sebagaimanapenjelasan yang lalu.

Bertolak dari dasar-dasar dan batasan-batasan kontekstual tersebut di atas maka langkah-langkah pemahaman kontekstualdapat dilakukan sebagai berikut:

1. Memahami teks-teks hadis atau sunnah untuk menemukan dan mengidentifikasi legal spesifik dan moral ideal dengan cara melihat konteks lingkungan awalnya yaitu; Makkah,Madinah dan sekitarnya.

2. Memahami lingkungan baru di mana teks-teks akan diaplikasikan, sekaligus membandingkan dengan lingkunganawal untuk menemukan perbedaan dan persamaannya.

3. Jika ternyata perbedaannya lebih esensial dari persamaannya maka dilakukan penyesuaian pada legal spesifik teks-teks tersebut dengan konteks lingkungan baru, dengan tetapberpegang pada moral idealnya. Namun jika ternyatasebaliknya, maka nas-nas tersebut diaplikasikan dengan tanpaadanya penyesuaian.

Langkah-langkah itu perlu ditaati sebagai rambu-rambu, agar tidak sampai terjadi penafsiran liar, yang pada akhirnya hadis bisa dibawa kemana angin 
bertiup, artinya mengikuti kepentinganmanusia yang bersumber dari hawa nafsu. $^{18}$

\section{AplikasiHadits dengan Pendekatan Tekstual dan Kontekstual}

Agar lebih memahami hadits dengan pendekatan tekstual dan kontekstual, maka kita bisa melihat dari sisi matan hadits, yang mana ungkapan matan hadits mempunyai beberapa corak atau model, diantaranya:

1. Jawami' al-Kalim (Ungkapan singkat namun padat makna)

Nabi bersabda :

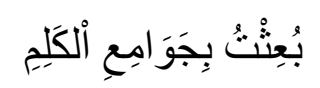

“ Saya dibangkit (Oleh Allah) dengan (kemampuan untuk menyatakan) ungkapan-ungkapan yang singkat, namun padat makna. (HR. Al-Bukhari, Muslim, dan lain-lain, dari Abu Hurairah).

Berdasarkan pernyataan Nabi tersebut diatas maka tidaklah mengherankan bila banyak dijumpai matan hadist Nabi yang berbentuk Jawami' al-kalim. Hal ini merupakan salah satu keutamaan yang dimiliki oleh sabda-sabda Nabi. ${ }^{19}$ Sebagai contoh :

Minuman Khamar

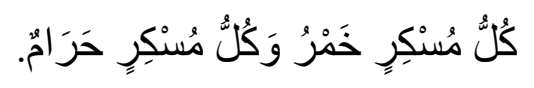

"Setiap (minuman) yang memabukkan adalah khamar dan setiap (minuman) yang memabukkan adalah haram. (HR. Al-Bukhari Muslim dll, dari Ibnu Umar dengan lafal dari riwayat Muslim).

Hadist tersebut secara tekstual memberi petunjuk bahwa keharaman khamar tidak terikat oleh waktu dan tempat. Dalam hubunganya dengan kebijaksanaan

${ }^{18}$ Liliek Channa AW, http:/ / ejurnal.iainmataram.ac.id/index.php/ulumuna/article/view/205/pdf_98 Edi Safri, Al-Imâm alSyafi'i: Metode Penyelesaian Hadis-Hadis Mukhtalif, Tesis. Diakses 15 November 2016 pukul 13.00 WIB. 1994), hlm 10

${ }^{19}$ Dr. H.M.Syuhudi Ismail, Hadis Nabi yang Tekstual dan Kontekstual (Jakarta: PT Bulan Bintang, 
dakwah, dispensasi kepada orang-orang tertentu yang dibolehkan untuk sementara waktu meminum khamar memang ada sebagaimna yang dapat dipahami dari proses keharaman khamar dalam Al-Qur'an.

Dari beberapa kutipan hadist Nabi di atas dapatlah dinyatakan bahwa pada umunya, hadist-hadist Nabi yang berbentuk Jawami'al-kalim menuntut pemahaman secara tekstual dan menunjukkan bagian dari ajaran Islam yang Universal. Dalam pada itu, diantara hadist yang berbentuk jawami'al kalim tersebut, ada juga yang dapat dilakukan pemahaman secara kontekstual dan menunjukkan adanya bagian ajaran islam yang bersifat temporal, disamping yang universal. $^{20}$

\section{Bahasa Tamsil (Perumpamaan)}

Sebagai contoh hadis Nabi :

Kembali dari Haji Seperti Bayi

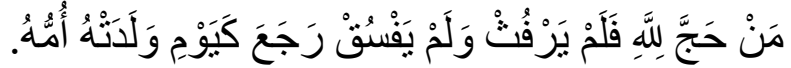

“ Barangsiapa melaksanakan ibadah haji karena Allah semata, lalu (selama melaksanakan ibada haji itu) dia tidak melakukan pelanggaran seksual dan tidak berbuat fisik, niscaya dia kembali (dalam keadaan bersih dari dosa dan kesalahan) seperti pada hari dia dilahirkan oleh ibunya. (HR Al-Bukhari Muslim dll, dari Abu Hurairah).

Secara Tekstual, hadis tersebut mengibaratkan orang yang berhasil menunaikan ibadah haji menurut petunjuk syariah sebagai hari yang dia itu baru saja dilahirkan oleh ibunya. Tegasnya, dia itu seperti bayi yang baru dilahirkan oleh Ibunya.

Pemahaman secara kontekstual terhadap petunjuk hadis tersebut ialah bahwa bagi orang yang berhasil menunaikan ibdah haji menurut petunjuk syariah, maka dia diampuni segala dosanya dan dimaafkan segala kesalahannya oleh Allah, sehingga dia seperti tatkala baru dilahirkan ibunya.

${ }^{20}$ Ibid, hlm 12- 13 
Dari pembahasan secara kontekstual terhadap hadis-hadis yang berbentuk tamsil sebagaimana telah dikutuip diatas dapatlah disimpulkan bahwa ajaran Islam yang dikemukakanya bersifat universal. ${ }^{21}$

3. Ramzi (Ungkapan Simbolik)

Sebagai contoh Hadis Nabi :

Ususnya Orang Mukmin dan Orang Kafir

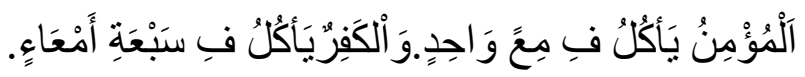

"Orang yang beriman itu makan dengan satu usus (perut), sedang orang kafir makan dengan tujuh usus. (HR Al-Bukhari, Al-Turmudzi, dan Ahmad, dari Ibnu' Umar.

Secara tekstual, hadist tersebut menjelaskan bahwa ususnya orang yang beriman berbeda dengan ususnya orang kafir. Padahal dalam kenyataan yang lazim perbedaan anatomi tubuh manusia tidak disebabkan oleh perbedaan iman. Dengan demikian, pernyataan hadist itu merupakan ungkapan simbolik. Itu berarti harus dipahami secara kontesktual. ${ }^{22}$

4. Dialog (Bahasa Percakapan)

Sebagai contoh hadis Nabi :

Kata Kunci tentang Islam

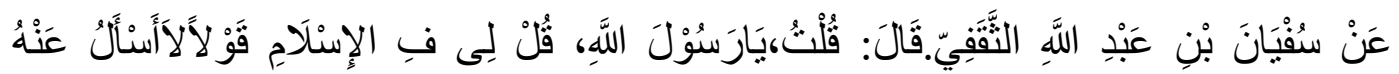

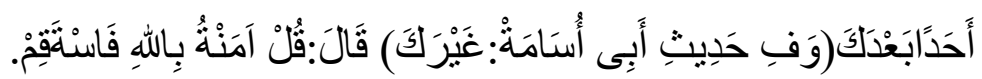

“ (Hadis riwayat) dari Sufyan bin Abd Allah al-Tsaqafi, dia berkata: " Saya bertanya: Ya Rasulullah, katakanlah kepada saya sebuah pernyataan tentang Islam, (sehingga) saya tidak lagi perlu bertanya kepada orang lain sesudah anda (dalam hadist riwayat Abu Usamah dinyatakan: selain anda). Beliau menjawab: katakan: 'saya beriman kepada Allah', lalu berpegang teguhlah kamu ( dengan pernyataanmu itu)!”. (HR Muslim dan Ahmad)

${ }^{21}$ Ibid, hlm 16

${ }^{22}$ Ibid, hlm 21 
Hadist ini mengemukakan "kata kunci” bagi seluruh ajaran Islam. Kata kunci itu ialah pernyataan beriman kepada Allah dan berusaha keras untuk berpegang teguh atas pernyataan keimanan itu. Kata kunci tersebut tidak hanya berlaku bagi Sufyan bin Aabd Allah al-Tsaqafi saja, tetapi juga berlaku bagi siapa saja yang menyatakan diri sebagai orang yang beriman sebagaimna yang dinyatakan oleh AlQur'an. Itu berarti, secara tekstual ajaran yang dikandung oleh hadist tersebut bukan bersifat temporal ataupun lokal, melainkan bersifat universal. ${ }^{23}$

5. Qiyasi (Ungkapan Analogi)

Sebagai contoh hadist Nabi:Pernyataan Hasrat Seksual yang Bernilai Sedekah. Dalam suatu matan hadis Nabi yang cukup panjang dikemukakan bahwa antara lain bahwa menyalurkan hasrat seksual (kepada wanita yang halal) adalah sedekah. Atas pernyataan Nabi itu, para sahabat bertanya: "Apakah menyalurkan hasrat seksual kami (kepada istri-istri kami) mendapat pahala?” Nabi menjawab:

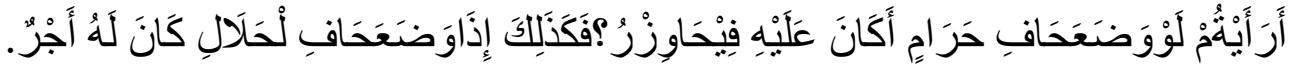

"Bagaimanakah pendapatmu sekiranya hasrat seksual (seseorang) disalurkanya dijalan haram, apakah (dia) menanggung dosa? Maka demikianlah, bila hasrat seksual disalurkan ke jalan yang halal, dia mendapat pahala. (HR. Muslim, dari Abu Dzar).

Matan hadist dalam bentuk ungkapan analogi tersebut menyatakan bahwa kalau penyaluran hasrat seksual secara haram adalah dosa, maka penyaluran hasrat seksual secara halal merupakan perbuatan yang diberi pahala. Dengan demikian dapat dinyatakan bahwa secara tekstual, hadist tersebut telah memberi petunjuk tentang ajaran Islam yang bersifat universal sebab ketentuan itu berlaku untuk semua waktu dan tempat. ${ }^{24}$

\section{Kesimpulan}


Pendekatan tekstual dan Kontekstual sangat berarti dalam pemahaman keilmuan hadits. Dengan pendekatan tekstual dan kontekstual kita ketahui bahwa suatu hadits muncul tidak serta merta begitu saja, melainkan karena ada sebabmusababnya. Pendekatan tekstual lebih cenderung berlaku pada ibadah mahdah (murni) antara hubungan manusia dengan Tuhan (Hablumminallah) seperti Shalat misalnya.

Sedangkan pendekatan kontekstual lebih melihat pada konteks historis, sosiologis dalam kultural dan temporal suatu hadits sehingga dalam memahami hadits tidaklah begitu baku tapi lebih bijaksana dengan mengkaji keadaan kontemporer masyarakat sekarang tanpa menghilangkan ruh dari nash hadits tersebut.

\section{Saran}

Dalam memahami hadits hendaklah menuntut ilmu sebanyak-banyaknya berkenaan dengan hal tersebut semisal studi hadits berkenaan dengan teori dan metodologi karena masih banyak ditemukan yang keliru dalam memahami hadits sehingga lebih frontal dan radikal. Setelah mempelajari pendekatan tekstual dan kontekstual diharapkan mampu memahami hadits dengan benar.

\section{DAFTAR PUSTAKA}

Al-Ghazali, Syaikh Muhammad, 1996, Studi Kritis Atas Hadis Nabi Antara Pemahaman Tekstual dan Kontekstual, (Bandung: Mizan)

Ismail,yuhudi, 1994, Hadis Nabiyang Tekstual dan Kontekstual (Jakarta: PT Bulan Bintang, Juned, Daniel, 2010, Ilmu Hadits:Paradigma Baru dan Rekonstruksi Ilmu Hadits, (Yogyakarta: Erlangga,)

Liliek Channa AW, Memahami Makna Hadis secara Tekstual dan Kontekstual, Jurnal Studi Keislaman, vol xv no 02, Desember 2011, http://ejurnal.iainmataram.ac.id/index.php/ulumuna/article/view/205/pdf_9 8 Edi Safri, Al-Imâm al-Syafi'i: Metode Penyelesaian Hadis-Hadis Mukbtalif, Tesis. Diakses 15 November 2016 pukul 13.00 WIB Munawwar, Said Agil Husin, 2001, Asbabul Wurud Studi Kritis Hadis Nabi Pendekatan Sosio-Historis-Kontekstual (Yogyakarta: Pustaka Pelajar) 
Rahman, Fazlur, 2002, "Wacana Studi Hadis Kontemporer" dalamBunga Rampai Wacana Studi Hadis Kontemporer, ed. Hamim Ilyas dan Suryadi(Yogyakarta: Tiara Wacana,) Tim Penyusun Kamus Pusat Pembinaan dan pengembangan Bahasa, 1998, Kamus Besar Bahasa Indonesia, (Jakarta: Balai Pustaka,) 